\title{
Word versus Honour: the case of Françoise de Rohan vs. Jacques de Savoie
}

\author{
Una McIlvenna \\ University of Sydney
}

\begin{abstract}
This paper examines one of the most notorious scandals of sixteenth-century France. In 1557, Françoise de Rohan, a lady-in-waiting to Catherine de Medici, launched a legal battle to get the duke of Nemours, Jacques de Savoie, to recognise their orally-agreed marriage contract and formally recognise the child whom he had fathered with her. Central to Rohan's case were not only the love-letters Nemours had written to her but also the eye-witness testimonies of her servants, who had overheard their marriage vows and had witnessed their love-making. Nemours's only defence was his word of honour as a gentleman that no marriage had taken place. This paper situates the case of Rohan vs. Nemours within a transitory period in French society as oral and literate cultures competed for precedence, and asks what happens to the concept of honour when the spoken word is no longer to be trusted.
\end{abstract}

\section{Keywords}

France, court, gossip, rumour, clandestine marriage, Françoise de Rohan, Jacques de Savoie, Catherine de Medici

\section{Introduction}

Upon the fifth of May the obscene, withered, Putrid, worn-out harlot again seeks men for her marriage bed. Likewise he who marries her is wicked, treacherous, lawless, Bankrupt, adulterous, accursed, disloyal and worthy of torture. ${ }^{1}$

These charming lines were written in 1566 to commemorate the wedding of Anne d'Este, duchess of Guise, grand-daughter of Louis XII of France and lady-in-waiting to the queen mother Catherine de Medici, and her new husband, Jacques de Savoie, duke of Nemours, the hero of the French campaigns in Italy. That such vitriolic terms could be used to describe a granddaughter of France and the kingdom's arguably most successful warrior is an indication of the public resentment felt at the circumstances surrounding their wedding. For ten years Nemours had been engaged in a bitter dispute with his former lover, Françoise de Rohan, also a lady-in-waiting to Catherine de Medici. ${ }^{2}$ The duke's refusal to honour either an earlier secret, oral agreement of marriage with Rohan, or the child that was produced from their 
relationship, would become the matter of legal debate for over twenty years, causing a fourway jurisdictional battle between France's leading sovereign law court, the Parlement of Paris, the King's private council, the Gallican Church and the Vatican Rota, and the familial feuds the case inflamed threatened to ignite further civil war. ${ }^{3}$

In this period of heightened religious tension and bloody conflict that would divide families both peasant and noble, the perennial tale of the seduction and betrayal of a naive woman may at first appear frivolous. However, the Rohan-Nemours story offers a fascinating case study of how orality played a central role in the construction of honour and reputation at the early modern court. The documents relating to the legal case allow us to recreate the oral and aural world within the court, and to explore the overlap and interweaving of orality and literacy in different genres of communication: how eavesdropping found its way into legal depositions and gossip into private correspondence. The role of rumour and gossip in this case is revelatory as to the structures, networks and divisions that characterised the court, and demonstrates how social class and, occasionally, gender could dictate how information was transmitted within the palace walls and disseminated beyond them into the public arena. The personal and political fallout from the dispute demonstrate the consequences for an elite woman's reputation, and that of her family, when she chose to make private, domestic matters public. Furthermore, this paper explores the legal and social context in which the scandal was based. The French legal system in the sixteenth century was in a state of flux, with the laws on marriage under constant debate and the precedence of oral testimony being gradually superseded by a new literate culture where the written word was considered more valuable. ${ }^{4}$ These developments would affect, and be affected by, the high-profile case of Rohan vs. Nemours which exposed the tensions between oral, aural and written evidence. 


\section{Secret Agreements}

Around 1553, the duke, a partisan of the pro-Catholic Guise faction, began an amorous relationship with Mlle de Rohan, first cousin to Jeanne d'Albret, the Huguenot queen of Navarre. While in Italy in 1555, however, he was involved in negotiations to marry Lucrezia d'Este, sister of the duke of Ferrara and the aforementioned Anne d'Este, but when rumours of the negotiations reached Rohan, Nemours vehemently denied them. In early 1556, Nemours allegedly agreed a secret, oral marriage contract with Rohan and they soon thereafter began a sexual relationship. By June she was pregnant, but did not inform Nemours until he had left on military campaigns in Italy in November. When the duke refused to honour the oral agreement by solemnizing their marriage in church, Rohan sued him for breach of promise.

The written evidence of the case reveals the royal court to have been a porous environment where the control of sensitive information was rendered almost impossible by the gossip of ever-present servants who, despite their illiteracy - or perhaps because of it - could recall an extraordinary amount of detail about interpersonal transactions. In March 1559, before the bishop of Paris's tribunal, Rohan produced twelve letters from Nemours in which he repeatedly professed his intentions to spend the rest of his life with her, but simultaneously implored her secrecy in the matter. She also called five of her domestic servants - her governess, her tailor, her page, her valet and her maid - as eyewitnesses to their secret vows, to their sexual activities and to his repeated claims to be Rohan's husband. ${ }^{5}$

Notwithstanding their potentially tendentious nature, the depositions nonetheless reveal a constant presence of servants around her, so ubiquitous as to sometimes go unnamed in the depositions, as if they were part of the furniture. Their quasi-invisibility resulted in their witnessing the most intimate details of her life, reading and keeping her letters, even watching 
her have sex. Rohan's tailor Fleury Barge described how, after falling asleep on a chest next to Rohan's bed one evening, he was woken by the couple having sex. He was able to describe their clothes in detail, including the petticoat Rohan was wearing which he himself had made. ${ }^{6}$ Her page, Antoine de Coué, related another occasion when, dining with at least four other servants at a table near Rohan's bed, he "heard the said lady cry out which made him turn his head towards the bed and saw the said lord de Nemours and the lady Rohan making the act of husband and wife." "7 Her governess, Gabrielle de Binel, dame de Coué, described a similar incident which significantly confirmed both Nemours's verbal insistence upon their married status and the lack of privacy in the domestic environment of the court. She came into the room where she saw and found the said lord duke upright against the bed of the said lady and performing the actions of husband and wife. And as soon as the said lady Rohan noticed the said deponent enter she pulled away. And then the said lord duke seeing that the said lady Rohan pulled away out of shame said to her, in a voice that was bitter and deep and full of anger, these words, swearing: "Mort dieu! What are you scared of? Am I not your husband? Are you not my wife?" To which the said lady replied, "Yes, sir," which the said deponent heard clearly and assuredly, and in the room were the girls and ladies of the said lady Rohan...

Binel's testimony evokes the densely-populated living quarters of the royal palace, where the unnamed "girls and ladies of the said lady Rohan" were in the same room while the couple had sex, and where Rohan's servants could easily hear her private conversations. ${ }^{9}$

All of the servants were in agreement that Rohan and Nemours were a married couple. After all, they had not only witnessed their love-making; they had even heard them exchange marriage vows. Her chambermaid Perrine Legrand testified that, while doing some last-minute 
sewing before Rohan's planned trip to Brittany in 1556, she overheard the duke pleading with Rohan:

"I know well that when you are in Brittany that madame your mother wants to marry you. I beg you to not get married because you know well the agreement there is between us both." And with these words the said deponent heard the said lord say to the said lady these words, "I take you for my wife" and the said lady said to the said lord, "I take you for my husband." And having done this they kissed each other. ${ }^{10}$ According to Binel, "the common gossip of the whole household of the said lady and other non-domestic staff who frequented the said house was that the said lord duke was the true husband of the said lady and was regarded and reputed as such."11 The numerous references in the depositions to rumour and gossip - "bruit" in French - highlights the reliance on the spoken word by servants whose illiteracy meant that some were unable to even sign their own depositions. The details that Binel was able to recall about the nature of the sound of Nemours's voice ("bitter and deep and full of anger") demonstrate a familiarity with an oral culture that is difficult for a modern literate observer to fully appreciate.

This is combined with an early modern perception of time in which dates are described in terms of saints' holidays or major events at court. Fleury Barge recalled an incident taking place "the court being at Fontainebleau, around the feast of St. Jean, when the queen had given birth to two children". ${ }^{12}$ Although they are generally unclear of their own age or birthdate (Antoine de Coué described himself as "aged from twenty-three to twenty-four or thereabouts" ${ }^{\prime 13}$ ), the passing of time is precisely marked by aural signals: several witnesses distinctly remembered that Nemours would leave Rohan's chamber at lam because they could hear the changing of the guard around the king's bedroom. Thus, despite their lack of literacy, 
the servants' depositions are full of precise, informative details about a world they experienced both orally and aurally.

This trust the servants placed in the spoken word was exploited by Nemours whenever he was challenged by Binel about his intentions concerning her mistress:

To which the said lord duke made reply that he was a man of worth, swearing the name of the Lord like "Mort-Dieu!" and other oaths, that he had promised marriage to the said lady Rohan, and would marry her, that she was assured of him and that she knew it well. And when the said deponent chided the said lord, "Yes, my lord, but if you do not marry her look at the danger you will put us all in," then the said lord started swearing like before saying, "I believe, Miss Coué, that you do not take me for

a man of worth. I am neither so evil nor so wicked as to wish to deceive her." 14

In the early modern society where orality was paramount, where preachers' sermons were a powerful political weapon and where most people experienced books by listening to another person read them out loud, Rohan's claim that Nemours had reneged on his oral promises was a scandalous and troubling accusation. As a sacrament, marriage depended on the oral exchange of vows, not on public ceremony or written certificates. It was a society where, as Nemours himself claimed, a gentleman's honour was based on him keeping his word; if it could be shown that he had backed out on his promise, his own reputation was at risk. As Antoine de Bourbon, king of Navarre and husband of Rohan's cousin, Jeanne d'Albret, wrote about the affair: "it seems to me that he cannot back out of it without damaging his honour.",15

\section{The Scandal of Clandestine Marriage}

For aristocratic families, an unarranged marriage was unthinkable, as a successful union was both a business transaction that benefitted a family in terms of landholdings, social status and 
financial assets and, crucially, a public performance that displayed a family's ability to succeed in those areas. ${ }^{16}$ A noble marriage, clandestine or not, had consequences not only for the couple but also for their unmarried siblings, who could benefit from a lucrative marriage in terms of the increased dowries and elevated status that a spouse from a more prestigious family could bring, or their own marriage plans could be thwarted by the shame and/or financial ruin brought upon the entire family by a mésalliance. Romeo and Juliet was not simply a story about star-crossed lovers: the perennial phenomenon of clandestine marriages in early modern France was a matter of such overwhelming concern to parents that every ordinance of the sixteenth century reinforced severe penalties for those found guilty of marrying in secret. Traditionally, the Catholic Church sanctioned marriage with only the consent of the couple, who had only to speak their intention (verba de futuro), followed either by more words declaring the mutual and present will of the couple (verba de praesenti) or by action: carnal union. ${ }^{17}$ It would be this second option that Rohan would claim had occurred: intention (their secret vows) followed by action (sexual intercourse). However, in its twentyfourth session, the Council of Trent attempted to introduce greater control of the Church in family matters by requiring the presence of a priest and two witnesses at the exchange of vows, although it did not require the consent of parents. The Gallican Church's resentment of interference from Rome in its domestic matters, however, meant that it would never ratify the Council's decrees.

In practice, French law would nevertheless move towards the spirit of the Tridentine marriage regulations after the scandalous case in 1556 of François de Montmorency and Jeanne de Piennes. François's father, the Constable Anne de Montmorency, Henri II’s most trusted adviser, had arranged for his son to marry the king's daughter until François admitted to having already secretly married his lover, Jeanne de Piennes. ${ }^{18}$ The enraged father encouraged 
Henri II to publish a royal edict that year that dramatically altered the laws. ${ }^{19}$ The edict raised the age of consent for women to twenty-five and for men to thirty, disinherited contractors of marriages made without parental consent, and required priests performing weddings to publish the banns of marriage before they took place, to ensure that there were four witnesses, rather than two, and to know the age of the couple. It would appear that the new laws were not routinely enforced, however, as in 1576 the Estates General at Blois called for a stronger ban on clandestine marriages, complaining that "clandestine marriages and in consequence bigamies and disastrous unions were ruining families and defying discipline." ${ }^{20}$ The resulting Ordinance of Blois in 1579 prescribed the keeping of registers of marriage, the public calling of the banns of marriage, a public celebration, and the necessary presence of the priest and four witnesses. ${ }^{21}$ Priests were forbidden to perform marriage ceremonies for persons from outside their parishes in the expectation that this would reduce the opportunities for secret marriages. It also declared that those responsible for such a marriage, usually but not always the would-be husband, were guilty of the capital crime of rapt (either by seduction or abduction). ${ }^{22}$ Given that clandestine marriages now incurred the penalties of disinheritance and capital punishment, the ordinance reflects the concern raised by secret marriages. ${ }^{23}$

All these measures would come too late to affect the Rohan/Nemours case, but they highlight the perennial desire for couples to defy parental wishes regarding appropriate spouses and the shifting conditions and resulting confusion around clandestine marriage which repeated legislation was trying to erase. It is important to understand that at no time did Nemours claim that the marriage was invalid because it had been conducted clandestinely, for all were aware that Rohan's argument - that oral vows followed by sexual intercourse equalled binding marriage - was a valid one. Nemours's only defence was to claim that the vows had never 
taken place, and to claim that Rohan's servants had therefore been bribed to give evidence against him.

Fortunately for Nemours, political events intervened. On 30 June 1559 Henri II was accidentally killed and the young François II and his Guise bride, Marie Stuart, ascended the throne. Her uncles, the Guise brothers, became de facto rulers of France, and Nemours found himself with powerful allies at court. Accordingly, in response to the eyewitness accounts given by mere servants, Nemours invoked the testimony of the most powerful nobles in the kingdom, including members of the royal family itself. The late king's sister, Marguerite de France; the cardinal of Lorraine; the late king's mistress, Diane de Poitiers; the royal surgeon, Ambroise Paré; and even Rohan's mistress, Catherine de Medici, all gave testimony on Nemours's behalf. ${ }^{24}$

Catherine, dismayed at the scandal caused to the reputation of her household by Rohan's pursuit of a high-profile legal case, gave a deposition on 1 August 1559 that was damning to her former lady-in-waiting. Catherine claimed that, when she confronted Rohan shortly before Nemours's departure for Italy, Rohan had denied being pregnant, blaming pregnancy rumours on malicious gossip by other courtiers. Not convinced, Catherine claimed that the following day she commanded her own doctor Sallon not to agree to Rohan's request to bleed her footan action thought to redirect "blocked" menstrual flow during missed periods - but Sallon admitted that he had already refused two such requests from Rohan because he was aware of the same rumours of pregnancy - testament to how widespread those rumours had become. ${ }^{25}$ Interestingly, Catherine did not claim to have divulged any of this intimate information to Nemours before his departure. 
Indeed, the hierarchy of transmission of pertinent information between less well-connected nobles such as Rohan and more powerful nobles such as Nemours can be seen in the deposition by Rohan's governess Binel, as she described hearing about Nemours's marriage negotiations with Lucrezia d'Este. She said

that she had been warned by one of the Queen's ladies-in-waiting who had heard it being said to the signora Olivia, who said she had heard it being said to Madame de Guise that the said Sr. de Nemours had promised Madame de Guise that he would marry one [of her] sisters. ${ }^{26}$

The tortuous path by which Binel received the information, relying on fourth-hand hearsay and gossip, stands in stark contrast to the deposition of the late king's mistress, Diane de Poitiers. While Diane mentioned that "there was a rumour that the said duke of Nemours went to Italy to see madame Lucrezia, and that he might wed her," she also admitted that she "did not know however if the damoiselle plaintiff [Rohan] knew anything about the said rumour of marriage. ${ }^{, 27}$ Evidently Diane did not feel it necessary to pass on the information herself. An anonymous letter in the Bibliothèque nationale de France which I have identified as Rohan's personally-written reply to one of Nemours's letters, refers to the marriage negotiations with Lucrezia d'Este, demonstrating how Rohan clearly relied on Nemours to provide her with information about the negotiations:

Regarding the marriage of the lady whom you know, I know as much from what you have told me about it that I am not afraid at all that she will do me this wrong... ${ }^{28}$ Although her sentiments may have been disingenuous, this long letter in which Rohan repeatedly enthused about her own faith in Nemours's honour demonstrates that she appeared to value Nemours's claims over those of her governess. Had Rohan consulted her mistress Catherine directly (which never seems to have happened) she would, however, have been given more relevant details about the matter. 
But the impression given by the testimony of the leading nobles is of a wealth of information available only to a privileged few. Catherine, who as head of her female household had a responsibility to her younger ladies to prepare them for the marriage market, never conveyed to Rohan the vital information that the Este negotiations were underway, nor Nemours's admission to the king's sister, Marguerite de France, that since his return from Italy he had had no intention of marrying Rohan. Instead, when Rohan's pregnancy was confirmed in January 1557, Catherine belatedly scolded the governess Binel for allowing Nemours into the room after she had forbidden it. Binel simply replied "that she could not honestly refuse entry to such an honest prince." 29

\section{From Words to Actions}

This world of overheard private conversations within the walls of the palace would soon be brought into the public sphere as the political situation took a new turn. In December 1560 , Catherine assumed the regency and began to attempt to introduce a measure of toleration for Protestants, a position implemented at the Estates-General in Orléans a few weeks later. Capitalising on the new-found support for their religion at court, in February 1561, Rohan's brothers arrived at court with two hundred armed men to force Nemours to marry their sister. Their arrival, however, threatened to undo Catherine's efforts at reconciliation. The Florentine ambassador described the tensions that their presence caused:

It seems that M. de Nemours has become suspicious, and so with the help of M. de Guise, has armed himself in his house, and outside still goes well accompanied.... This quarrel is not finished, but nevertheless it escalates, nor do there lack people who foment it... And the Guise have had the worst of it, because they are universally hated, 
and everyone wishes they would go away, and shouts after them; and all of this is done so that they might be driven out. ${ }^{30}$

The ambassador's comments reveal the escalating animosity that the case was creating between the already-feuding Guises and Bourbons, and the damage it was causing to the reputations of the Guises as well as Nemours.

Although that particular crisis was averted, the bad blood between the two families because of the case would spill over, in February 1564, into a fatal battle in the streets:

This night at Paris a gentleman of Bretagne, belonging to the Duke of Nemours, called Caharon, met M. De Fontenay, younger brother to M. De Rohan, riding in the street, and with his rapier thrust him through the left shoulder, thinking that he had slain him. De Fontenay alighted, and, with another captain, followed him, and hard at the house of Guise overtook him and slew him. The captain who was with Fontenay hurt another that was with Caharon in the head, so that he is like to die. The quarrel was for words Caharon should speak of Fontenay. ${ }^{31}$

These "words" are what the French would have described as a démenti, the insulting words used to provoke a duel, and are an example of how, in this predominantly oral culture, the spoken word could be immediately transformed into physical acts of violence. The case of Rohan vs. Nemours both epitomised and antagonised the confessional tensions that had only recently plunged the country into civil war. The historian Jacques-Auguste de Thou would remember it thus: 'As the duke of Nemours had at that time more credit, and as there was much distancing from and hatred for the Protestant religion, to which Françoise de Rohan was attached, the suit was thrown out through the intervention of the Pope' ${ }^{32}$ For the Huguenots, the case came to represent everything against which they were struggling, and Nemours's alleged lies and promiscuity were depicted as the worst kind of Popish excess. It was not 
simply a matter of Protestant against Catholic; Rohan's argument was about honesty versus duplicity, about transparency over corruption. A 1566 poem addressed to the king after a verdict went against Rohan claimed that the corruption in the church and the courts was inherently linked. Reform was needed in both 'the great Idolatry', meaning the Catholic Church, and 'the great Parlement', the country's leading law court. ${ }^{33}$ The king's personal slogan of 'Mercy and Justice' was being made a mockery of, claimed the author, 'since your judges judge all to their guise', a pun that alluded to the pervasive and unfair influence the Guise family had in both institutions, influence that guaranteed an unfavourable verdict for Rohan. Antoine de Navarre's comments reveal how strictly the Huguenots viewed the situation: "because I have hope that once he [Nemours] has considered everything well, that he can do no less than to go through with it; I mean either marriage or death.",34

Nemours was about to take Navarre at his word: on 2 September 1562, he wrote a secret letter to Rohan in which he offered to solemnise the marriage in Langey, near Tours on 25 September whereupon he would recognise her son as his legitimate heir on the grounds that she tell no one of their impending ceremony. ${ }^{35}$ If this was a plot to murder Rohan in order to put an end to the lawsuit it failed, and the letter was presented by Rohan's legal team as further written evidence of Nemours's duplicity. This extraordinary development was soon followed by another. In February 1563, Nemours's close friend and ally, the duke of Guise, was assassinated and his widow Anne d'Este was now free to marry the man originally promised to her sister: Jacques de Savoie, duke of Nemours. ${ }^{36}$ The only obstacle to their union was the tenaciously litigious Françoise de Rohan, who had launched endless appeals to have the case heard in the Parlement, France's fiercely independent sovereign law court. Nemours thus began to fully exploit both his political and affective influence with the king and queen mother (to whom Este was not simply a lady-in-waiting but also a very close friend) to have 
the case moved from the Parisian tribunal to Lyon where Nemours was governor and where the Archbishop was a partisan. Although this blatant corruption caused a storm of protest (including both verses already mentioned), the Archbishop's verdict in May 1566 allowed the marriage of Nemours and Este to go ahead.

The protest did not only manifest itself in written libels. The marriage would cause a rift between Rohan's cousin and defender Jeanne d'Albret and her old friend Renée, duchess of Ferrara. While both women were leading Calvinists and allies for many years, Renée was Anne d'Este's mother, and could not forgive the uncomplimentary remarks that Jeanne had made about her daughter. In May 1566, the English ambassador Thomas Hoby noted that, "Certain words of offence have passed between the Queen of Navarre and the old Duchess of Ferrara for the marriage of her daughter to M. De Nemours. ${ }^{\text {37 }}$ The Ferrarese ambassador was more explicit: "When [Jeanne] started to kiss her, as was her custom...Madama [refused] saying that she would never again allow lips as poisoned as [Jeanne's] to approach her." ${ }^{\text {,3 }}$ Similarly, the Spanish ambassador, Don Frances de Alava, described an argument between Jeanne d'Albret and Anne d'Este, in which he said they had "dishonoured themselves by squabbling like washerwomen over the subject of the marriage of the latter, unafraid to exchange offensive remarks in the presence of the entire court and the queen." 39 Orally uttered words could cause the breakdown of long-held alliances and networks. The oral transmission of information, the importance given to the spoken word, could backfire in a public and damaging way, reducing queens and duchesses to the status of "washerwomen." The ambassador's use of this term reveals how oral discussion of private matters in public was laden with ideas of social status and gender, with arguing about personal relationships reserved for the lowest class of female. 


\section{International Scandal}

Moreover, as these examples make clear, ambassadors enjoyed a privileged, but ambiguous status at court: a semi-constant presence at sensitive and important moments, they were used as agents of information both by their host nation and by those who wished to send information abroad. Their accounts of the feuding at court made their way back to Spain, England and Italy, damaging the reputations of all involved. The ambassadors' unique status as the embodiment of the absent sovereign would present an acute problem at the occasion of the Nemours/Este wedding on 5 May 1566. The entire court had been invited to the wedding at the chapel of the Abbaye de la Roquette, in Saint-Maur-des-Fossés. However, to avoid any possible disruption by supporters of Rohan, the great hall of the château had been secretly prepared, and the wedding was celebrated there by the Cardinal of Lorraine with the foreign ambassadors in attendance, as they would have interpreted their exclusion from the real wedding as a diplomatic affront. But the attempts at secrecy were futile: as the Cardinal was about to pronounce the sacramental words, an officer of the Parlement, Vincent Petit, rose to his feet and proclaimed that he represented the 'dame de Rohan' and that she forbade the marriage to proceed. The Cardinal faltered for a moment, but the officer was quickly removed and the ceremony continued. The English ambassador, Thomas Hoby, credited Petit's appearance to Jeanne d'Albret and reported back to London that he "was immediatlie committed to warde for a wholl day bicause he durst appeare in that place about such a matter without the kings speciall license which fact the Q of Navarr imputeth to want of iustice."40 The Spanish ambassador disclosed that the officer later continued his protest in front of the king's council, claiming that Nemours had raped Rohan and therefore "following the laws of France, deserved to have his head cut off, because he had taken Mme de Rohan by force in the queen's chamber and made her pregnant. A great laugh took hold of Catherine de Medici, Charles IX and the whole council! The lawyer was removed."41 
Petit's presence highlights the difficulties of keeping any information secret in the denselypopulated court environment, and the reports by the ambassadors ensured that Jeanne's anger at the injustice reached an international audience. Hoby claimed that public sentiment was outraged at a marriage under such dubious legal circumstances and that Nemours's reputation would suffer as a result: "This mariage, by commune reaport, is leeke to breed great trouble in fraunce, for all protestante and a nomber of papists are much against it and do not let to say that it shall cost him deere in the ende. He is a man universallie ill beloved, she generallie pitied." ${ }^{42}$ While the ambassador was a Protestant and therefore likely to be more sympathetic to Rohan, his reference to the "commune reaport" alluded to the negative public perception of the secrecy used to facilitate the marriage.

The reputations of both parties rested on what the different witnesses claimed to have heard being spoken. Sixteenth century French culture relied on the spoken word. Many letters between nobles contain little pertinent information except to recommend the bearer who will relay the information to the recipient orally. Kristen Neuschel explains that many of the most important messages between particularly intimate noble correspondents may have been wholly oral, wholly dependent on face-to-face encounters that left no documentary residue. ... their letters reflect the habits of dictating, of listening, and of trusting personally conveyed information. ${ }^{43}$

The need to be able to trust the spoken word was the bedrock of the honour system. To be an homme de bien, "a man of worth," demanded that a nobleman's actions correlated to his words. As Rohan, perhaps naively, expressed it in her letter to Nemours, 
I received the letter that you wrote me which was a really very great pleasure to know the truth; even though I was never in doubt that you were a man of worth, for had I been I would not have put as much faith in you as I have. ${ }^{44}$

That a leading noble such as Nemours - the "flower of all chivalry," as Brantôme described him - elected to back out on an orally-agreed contract threatened the very stability of the honour code. ${ }^{45}$ It was the most scandalous aspect of the case, more shocking than an illegitimate pregnancy or corruption of judges, and one of the key threats presented by clandestine marriages. However, while oral contracts were binding, once spoken they left no "documentary residue" - unless there were witnesses who also heard the words being spoken. The memories of Rohan's servants, to whom Nemours had showed so little regard as to have sexual intercourse with Rohan while they were present in the room, were transformed into written depositions that incessantly challenged Nemours's own version of events. Combined with the letters that he had thoughtlessly written, they created a paper trail in which Nemours's own words would eventually incriminate him.

This phenomenon in which the written version of an event superseded in authority the oral version was at that very moment becoming enshrined in law. The Ordinance of Moulins in 1566, the same year as the Nemours/Este wedding, decreed that in future, written proof took precedence over oral proof in legal cases involving over 100 francs. Previously, because so few people could read and write, oral proof was deemed more conclusive than written proof, and the accepted maxim was témoins passent lettres ("witnesses over letters"). After the ordinance the saying became lettres passent témoins ("letters over witnesses"). ${ }^{46}$ This major ideological shift in French legal culture reflected the newer privileging of written material, a cultural transformation that was problematic for those who continued to place a higher value in the oral transmission of information. Nemours's careless letter-writing in which, ironically, 
he asked for Rohan's silence and discretion exposed his traditional belief that it was the (un)spoken word that mattered rather than the written. However, now that his letters had become so imbued with value, it was fortunate for Nemours (some would say not coincidental) that when Rohan's home in La Garnache was sacked by Catholic forces during the second religious war in 1567 , many of her papers relating to the case were stolen.

Nevertheless, Rohan continued her legal appeal to have her marriage and son recognised. It was not only in the courts that she continued her legal argument: in December 1575, almost ten years after Nemours had married Este, Henri III forbade Rohan to use the name of "dame de Nemours, under pain of being declared recalcitrant and disobedient to decrees." Fashioning herself in public as well as in legal documents as Nemours's legitimate wife, Rohan had maintained a persona that as a result portrayed the duke as a liar, and thereby attacked his honour. She had not been alone in styling herself thus: Henri de Savoie, prince de Genevois, was the provocative title her son had given himself - provocative because it was the title given to the duke of Nemours's second son (also confusingly called Henri). The use of Nemours's name and coat-of-arms by the young Protestant warrior was a source of continuing antagonism for the duke, who was trying to raise his own family with Anne d'Este.

Surprisingly, it was Este herself, probably weary of being labelled an adulteress in every appeal by Rohan, who finally employed her superlative negotiating abilities to resolve the case. On 22 January 1580, after twenty-one years of ceaseless legal wrangling, Françoise de Rohan made a formal declaration, confirmed by letters patent of Henri III, that she and Jacques de Savoie had been secretly married, that their union had produced a son which he now recognised, and that because of his "adultery and infidelity" they were now divorced. ${ }^{48} \mathrm{In}$ 
return, and in an action that speaks volumes about the significance of the written word, Rohan was forced to relinquish all papers relating to the case.

\section{Conclusion}

Although early modern archival documents can appear on the surface to be dry and dusty, to the reader with an ear to orality they are alive with sound: the sounds of lovemaking, swearing, gossip, threats, insults, and laughter. The written documents relating to the RohanNemours case reveal a rich world of oral transactions, demonstrating the mostly unsuccessful attempts to create and maintain secrecy in the court environment. The centrality of marriage to the successful maintenance of the aristocratic society meant that details of the private romantic encounters of noble men and women were valuable intelligence, and this also explains the clandestine and duplicitous behaviour of both Rohan and Nemours. Her initial denial of the pregnancy, both to herself and others, can be explained by the stigma of illegitimate pregnancy, but her decision to reveal those intimate details in the courts was part of a strategy to defend herself by attacking Nemours's reputation as an honourable man. His seduction of Rohan, facilitated by his reputation as an "homme de bien," whilst he was secretly negotiating another marriage, was interpreted as an attack not just on her honour, but that of her entire family. The scandalous implication that he had gone back on his word as a gentleman was eventually confirmed by a legal ruling, but not after both parties had suffered grave slights on their reputations. Furthermore, the increasingly superior role of written testimony over oral testimony meant that Nemours could no longer rely simply on his own elevated status and that of his high-ranking witnesses to outrank and thereby dismiss the evidence of lowly, but eyewitness, servants. Valuing the spoken word over the written, it appears to have taken Nemours longer than Rohan to appreciate the legal significance of his letters and the servants' depositions. Her accumulation of written evidence, letters and eyewitness testimonies made 
her case resistant in the face of powerful opposition. The depositions, from both servant and

noble alike, reveal a densely-populated court environment, where higher ranked nobles

attempted to keep sensitive information within a privileged circle but where the ubiquity of

servants and ambassadors resulted in their presence at the most intimate of moments. A fertile

breeding-ground for rumour and gossip, the close quarters of the royal household provided

ample material for scandal, and the Rohan-Nemours dispute demonstrates how the gossip of

illiterate and generally ignored servants could escape the walls of the palace to reach an

international audience.

I would like to thank Elizabeth Horodowich and Filippo de Vivo for inviting me to present this paper at the Renaissance Society of America conference in Venice, April 2010, and the members of the round table for their subsequent comments. Many thanks also go to Rebecca McNamara, Noeleen McIlvenna, Evelyn Welch, and the anonymous readers of the journal for their suggestions and contributions to the final draft.

${ }^{1}$ National Archives UK (NA) SP 70/84, f. 356, "In nuptias Ducis de Nemours":

Sub nonas Maias meretrix obscaena, vieta

Putida, trita viris lectũ repetit genialem.

Ducit eã uxorĕ sceleratus, perfidus, exlex,

Decoctor, moechus, sacer, impius et cruce dignus.[...]

The verse, along with a French verse discussed further in this essay ("Sonet sur la devise du Roy"), formed the contents of an ambassadorial despatch from France to England; see Calendar of State Papers, Foreign Series, of the reign of Elizabeth (CSPF), ed. Joseph Stevenson (London, 1870), vol. 8, May 1566, no. 440.

${ }^{2}$ The case is thoroughly studied in Matthew A. Vester, Jacques de Savoie-Nemours: L'apanage du Genevois au coeur de la puissance dynastique savoyarde au XVIe siècle (Geneva, 2008), 67-109. It was also studied in the nineteenth century by Alphonse, baron de Ruble, Le duc de Nemours et Mademoiselle de Rohan (1531-1592) (Paris, 1883) and Comte Hector de La Ferrière, Trois amoureuses au XVIè siècle: Françoise de Rohan, Isabelle de Limeuil, La reine Margot (Paris, 1885). Given that his work is a biography of Nemours, Vester points out the positive biases of both earlier accounts towards Rohan.

${ }^{3}$ The Gallican Church refers to the Catholic Church in France and its assertion that the pope should have authority only over ecclesiastical matters, leaving temporal matters in the hands of the French monarch and bishops. This argument, eventually set out in the Declaration of the Clergy of France in 1682, was never accepted by the Holy See. The Rota is the highest appellate tribunal of the Roman Catholic Church.

${ }^{4}$ For studies of the relationship between orality and literacy, see Walter J. Ong, Orality and Literacy: the Technologizing of the Word (London, 1982); Jack Goody, The Interface Between the Written and the Oral (Cambridge, 1987); Literacy and Orality, eds. David R. Olson and Nancy Torrance (Cambridge, 1991).

${ }^{5}$ Bibliothèque nationale de France (BnF) MS Fr 3169, f. 47: deposition of Fleury Barge; f. 54: deposition of Pasquier Boucher; f. 59: deposition of Gabrielle Binel; f. 73: deposition of Antoine de Coué.

${ }^{6}$ BnF MS Fr 3169, f. 53, deposition of Fleury Barge.

${ }^{7}$ BnF MS Fr 3169, f. 37, deposition of Antoine de Coué: “ouit ladite dame s'escrier a raison de quoy tourna la teste du coste du lict et veit iceulx seigneur de nemours et dame de rohan faire acte de mary et femme."

${ }^{8}$ BnF MS Fr 3169, f. 32r, 32v, deposition of Gabrielle de Binel: "ou elle veit et trouva ledit seigneur duc debout contre le lict de ladite dame ....ant et faisant les oeuvres de mary et femme | Et soudain que ladite dame de rohan appercent ladite depposant entrer se retira | Et lors ledit seigneur duc voiant que ladite dame de rohan se retiroit de honte luy deist d'un voix aspre et basse ressentant sa colere ces motz en jurant mort dieu que craignez vous ne suis je pas vostre mary n'estes vous pas ma femme Aquoy respondit ladite dame ouy Monsr Ainsi que ladite depposan ouit et entendit clairement et asseurement et estoient en ladite chambre les filles et damoiselles de ladite dame de rohan." 
${ }^{9}$ For a detailed description of the logistics of life at court, including architectural plans of various royal châteaux, see Monique Chatenet, La cour de France au XVIe siècle: Vie sociale et architecture (Paris, 2002); also, "Les logis des femmes à la cour des derniers Valois” in Das Frauenzimmer. Die Frau bei Hofe in Spätmittelalter und früher Neuzeit. 6. Symposium der Residenzen-Kommission der Akademie der Wissenschaften in Göttingen, eds. Jan Hirschbiegel and Werner Paravicini (Stuttgart, 2000), 175-192.

${ }^{10}$ BnF MS Fr 3169, f. 41v, deposition of Perrine Legrand: "Je scay bien quant vous serez en bretagne que madame vre mere vous vouldre marier. Je vous prie ne vous mariez point car vous scavez bien les propos quil y a entre nous deux $\mid$ Et sur ces propos entendit ladite depposant que ledit signeur deist a ladite dame ces motz Je vous prendz pour ma femme Et ladite dame deist audit seigneur duc Je vous prendz pour mon mary Et en ce faisan se baiserent lun lautre."

${ }^{11}$ BnF MS Fr 3169, f.33r, deposition of Gabrielle de Binel: "le commun bruict de toute la maison de ladite dame et autres non domesticques hantans en ladite maison estoit que ledit seigneur duc estoit le vray mary deladite dame et estoit tenu et reputé pour tel."

${ }^{12}$ BnF MS Fr 3169, f. 53, deposition of Fleury Barge: "la court estant à Fontainebleau, environ la saint Jehan, au temps que la royne estoit accouchée de deux enfans."

${ }^{13}$ BnF MS Fr 3169, f. 37, deposition of Antoine de Coué: "agé de vingtrois a vingtquatre ans ou environ."

${ }^{14}$ BnF MS Fr 3169, f. 29r, 29v, deposition of Gabrielle de Binel: "A laquelle ledit $\mathrm{S}^{\mathrm{r}}$ duc feist response qu'il estoit homme de bien jurant le nom de dieu comme la mort dieu et autres sermens qu'il avoit promis mariage a ladite dame de rohan et lespouser Qu'elle estoit asseuree de luy et qu'elle le scavoit bien Et quant ladite depposant remonstroit audit seigneur Ouy Monseigneur mais si vous ne lespousiez regardez le danger auquel vous nous mectoiez | Lors se meist a juer ledit $\mathrm{S}^{\mathrm{r}}$ comme devant luy disant Je croy madamoiselle de coué que vous ne me pensez poinct homme de bien. je ne suis poinct si meschant ne si mallheureux que je la voulusse tromper."

${ }^{15}$ Lettres d'Antoine de Bourbon et de Jehanne d'Albret (Paris, 1877), 224, Antoine de Bourbon to Jeanne d'Albret, 1560: "me semble que il ne sen peult dédire sans à son honneur fère tort."

${ }^{16}$ For the laws concerning clandestine marriage and public opinion surrounding it in early modern Europe, see

Marian Rothstein, "Clandestine Marriage and Amadis de Gaule: The Text, the World, and the Reader," The Sixteenth Century Journal 25, no. 4 (1994): 873-886; Cathleen M. Bauschatz, "Rabelais and Marguerite de Navarre on Sixteenth-Century Views of Clandestine Marriage," The Sixteenth Century Journal 34, no. 2 (2003): 395-408; R. B. Outhwaite, Clandestine Marriage in England, 1500-1850 (London, 1995).

${ }^{17}$ Rothstein, "Clandestine Marriage and Amadis de Gaule," 879.

${ }^{18}$ Alphonse, baron de Ruble, François de Montmorency: Gouverneur de Paris et lieutenant du roi dans l'Isle de France (1530-1579) (Paris, 1880).

19 In her seminal essay on royal legislation around marriage in early modern France, Sarah Hanley expresses doubt that the Montmorency affair could have played a part in the edict. Sarah Hanley, "Engendering the State: Family Formation and State Building in Early Modern France”, French Historical Studies, vol. 16, no. 1. (Spring, 1989), 4-27. However, I disagree, arguing that François's age, then twenty-six, was the reason for the extremely high age of consent for males (thirty).

${ }^{20}$ Walter S. Johnson, Chapters in the History of French Law (Montreal, 1957), 250.

${ }^{21}$ Johnson, French Law, 250.

22 Jean Brissaud, A History of French Private Law, trans. Rapelje Howell (London, 1912), 116.

${ }^{23}$ Frederic J. Baumgartner, France in the Sixteenth Century (New York, 1995), 285.

${ }^{24}$ BnF MS Fr 3169, f.1: deposition of Catherine de Medici; f. 5: deposition of Cardinal de Lorraine; f.9: deposition of Constable Montmorency; f. 11: deposition of Marguerite de France; f. 14: deposition of Madeleine de Savoie; f.16: deposition of Diane de Poitiers; f. 20: deposition of Ambroise Paré.

${ }^{25}$ For early modern beliefs around menstruation and pregnancy, see Cathy McClive, "The hidden truths of the belly: the uncertainties of pregnancy in early modern Europe," Social History of Medicine 15 no. 2 (2002): 209227; ---, "Menstrual knowledge and medical practice in France, c. 1555-1761," in Menstruation: A Cultural History, eds. Gillian Howie and Andrew Shail (Basingstoke, 2005), 76-89.

${ }^{26}$ BnF MS Fr 3169, f. 31r, deposition of Gabrielle de Binel: "qu'elle avoit esté advertie par une des filles de la Royne qui avoit ouy dire a la seignora olivia qui disoit lavoir ouy dire a Madame de Guise que ledit Sr. de Nemours avoit promis a Madame de Guise deppouser une [illegible] seur."

${ }^{27}$ BnF MS Fr 3169, f. 16, deposition of Diane de Poitiers: "que le bruict couroit que ledict duc de Nemours alloit en Italie pour veoir madame Lucresse, que peult estre il l'espouseroit. Ne sait toutefois si ladicte damoiselle demanderesse sçavoit rien dudict bruict de mariage."

${ }^{28}$ BnF MS Fr 3397, f. 70, Françoise de Rohan to Jacques de Savoie: "quant au mariage de la dame que vous saves ie se tant ce que vous man aves dict que ie ne point de peur quelle me fase ce tort..."

${ }^{29}$ BnF MS Fr 3169, f.1, deposition of Catherine de Medici: “qu'elle ne pouvoit honnestement refuser l'entrée à ung si honneste prince." 
${ }^{30}$ Négociations diplomatiques de la France avec la Toscane, 6 vols., eds. Giuseppe Canestrini, Abel Desjardins, (Paris, 1859-1886), vol. 3, 444, Niccolo Tornabuoni to Cosimo I, trans. Rosa Salzberg: "pare che M. de Nemours sia insospettito, e così aiutato da M. de Guise, si sia armato in casa, e fuora ancora vadi bene accompagnato... Non è fornita questa lite, ma tuttavia va pullulando, nè manca chi accenda, come il Conestabile che non si sta. $\mathrm{E}$ Guisi n'hanno peggio, perchè hanno tutto l'odio dell' universale, e ciascuno vorria che se n'andassino, e gli gridono dietro; e tutto questo è fatto acciò diloggino."

${ }^{31}$ CSPF, vol. 7, 27 Jan 1564, no. 109 (8) 'Occurrences in France'. It appears that 'Fontenay' (Françoise's brother, Jean de Rohan, baron de Frontenay) was simultaneously experiencing marital difficulties of his own; see David Potter, "Marriage and Cruelty among the Protestant Nobility in Sixteenth-Century France: Diane de Barbançon and Jean de Rohan, 1561-7”, European History Quarterly, 1990, 20:5.

${ }^{32}$ Jacques-Auguste de Thou, Histoire universelle de Jacques-Auguste de Thou: depuis 1543. jusqu'en 1607,16 vols., (Londres [i.e. Paris], 1734), vol. 5, 185: “Comme le duc de Nemours avoit alors plus de crédit, \& qu'on avoit beaucoup d'éloignement \& de haine pour la Religion Protestante, à laquelle Françoise de Rohan étoit attachée; ce procès fut vuidé par l'entremise du Pape, \& le mariage du duc de Nemours avec Françoise de Rohan fut declaré nul." Jacques-Auguste's father, Christophe de Thou, was premier président of the Parlement of Paris while the case was under debate.

${ }^{33}$ NA SP 70/84 f. 356, "Sonet sur la devise du Roy". See note 1.

${ }^{34}$ Lettres d'Antoine de Bourbon et de Jehanne d'Albret, 222, Antoine de Bourbon to Jeanne d'Albret, 1560: "car j'ay espérance que le tout bien considéré de luy, qu'il ne peult moins que de passer par là, j'entens de mariage ou de mort."

${ }^{35}$ BnF MS Fr 3215, f. 71.

${ }^{36}$ For the details of this marriage arrangement from Este's perspective, see Christiane Coester, Schön wie Venus, mutig wie Mars: Anna d'Este, Herzogin von Guise und von Nemours, 1531-1607 (München, 2007).

${ }^{37}$ CSPF, vol. 8, 21 May 1566, Hoby to Cecil.

${ }^{38}$ Nancy Lyman Roelker, Queen of Navarre: Jeanne d'Albret 1528-1572 (Cambridge MA, 1968), 247.

${ }^{39}$ Pierre Champion, Catherine de Médicis présente à Charles IX son royaume 1564-1566 (Paris, 1937), 431-2:

"Enfin, Mme de Vendôme et Mme de Guise s'étaient déshonorées en se chamaillant comme des blanchisseuses (lavacerias) au sujet du mariage de cette dernière, ne craignant pas d'échanger des paroles malsonnantes en présence de toute la cour, et de la reine."

${ }^{40}$ CSPF, vol. 8, 16 May 1566, Hoby to Cecil.

${ }^{41}$ Champion, Catherine de Médicis, 429: "Mais le procureur avait continué son instance devant le conseil privé, affirmant que M. De Nemours, suivant les lois de France, méritait d'avoir la tête tranchée, car il avait pris de force Mme de Rohan dans la chambre de la reine et l'avait rendue enceinte. Un grand rire s'empara de Catherine de Médicis, de Charles IX et de tout le conseil! On fit sortir le procureur."

${ }^{42}$ CSPF, vol. 8, 4 May 1566, Hoby to Cecil.

${ }^{43}$ Kristen Neuschel, Word of Honor: Interpreting Noble Culture in Sixteenth-Century France (Ithaca, 1989), 114.

${ }^{44}$ BnF MS Fr 3397, f. 70, Françoise de Rohan to Jacques de Savoie: "ie receu la laitre que vour maves escrite qui ma este ung bien fort grant plesir de savoir la verite ancore que ie ne fust point an doute que vous ne fusies homme de bien car si ie i euse este ie ne me fuse tant fiee an vous comme ie suis..."

${ }^{45}$ Pierre de Bourdeille, abbé de Brantôme, Recueil des dames, poésies et tombeaux, ed. Etienne Vaucheret (Paris, 1991), 642: "le parangon de toute chevallerie."

46 Johnson, French Law, 250.

${ }^{47}$ Ruble, Le duc de Nemours, 132: “dame de Nemours, a peine d'estre declairee réfractaire et désobéissante aux arrêts."

${ }^{48}$ BnF MS Fr 3215, f. 13. 


\section{University Library}

\section{- M M I N E R VA A gateway to Melbourne's research publications}

Minerva Access is the Institutional Repository of The University of Melbourne

Author/s:

Mcllvenna, U

Title:

Word versus Honor: The Case of Francoise de Rohan vs. Jacques de Savoie

Date:

2012-01-01

Citation:

Mcllvenna, U. (2012). Word versus Honor: The Case of Francoise de Rohan vs.

Jacques de Savoie. Journal of Early Modern History, 16 (4-5), pp.315-334. https:// doi.org/10.1163/15700658-12342322.

Persistent Link:

http://hdl.handle.net/11343/124221 